\title{
New hermit crabs (Paguroidea, Anomura) from the Eocene of Huesca, Spain
}

\author{
Nuevos cangrejos ermitaños (Paguroidea, Anomura) del Eoceno de Huesca, España
}

Fernando A. Ferratges ${ }^{1, *}$, Pedro Artal ${ }^{2}$, Samuel Zamora ${ }^{3}$

${ }^{1}$ Departamento de Ciencias de la Tierra-IUCA, Universidad de Zaragoza, E-50009, Zaragoza, Spain.

${ }^{2}$ Museo Geológico del Seminario de Barcelona, Diputación 231, E-08007, Barcelona, Spain.

${ }^{3}$ Instituto Geológico y Minero de España, C/ Manuel Lasala, 44, 9B, E-50006, Zaragoza Spain.

* Corresponding author: (F. A. Ferratges) fer.afk87@gmail.com

\section{How to cite this article:}

Ferratges, F.A., Artal, P., Zamora, S., 2021, New hermit crabs (Paguroidea, Anomura) from the Eocene of Huesca, Spain: Boletín de la Sociedad Geológica Mexicana, 73 (3), A070121. http://dx.doi.org/10.18268/ BSGM2021v73n3a070121

Manuscript received: December 15, 2020

Corrected manuscript received: December 30, 2020 Manuscript accepted: January 5, 2020

Peer Reviewing under the responsibility of Universidad Nacional Autónoma de México.

This is an open access article under the CC BY-NC-SA license(https://creativecommons.org/licenses/by-nc-sa/4.0/)

\section{ABSTRACT}

A new genus and two new species of fossil hermit crabs (Anomura, Paguroidea) are described from the southern Pyrenean basins (Huesca, NE Spain). Parapetrochirus nov. with P. robustus n. gen., n. sp., as type species, comes from the lower Eocene (Ypresian) Roda Formation. It preserves both chelipeds exhibiting a notable heterochely, a larger left cheliped and a concavity without granulation in the inner upper portions. Eocalcinus gerardbretoni n. sp. comes from the highest levels of the Arguis Formation (Priabonian) in Yeste locality. This species is characterized by a hemispherical outline and a sinuous lower margin of the chela, which differs from the type species of the genus. The cheliped morphology of such species allows inclusion in the families Diogenidae and Calcinidae, respectively. Fossil paguroids are relatively rare in the Eocene of Spain, therefore, the description of these two new taxa increases the known diversity of this group. Parapetrochirus robustus n. gen., n. sp. inhabited siliciclastic substrates within a prodelta environment and $E$. gerardbretoni $\mathrm{n}$. sp. was collected from the last levels of coral rudstones just below the continental influence of Yeste-Arrés Formation.

Keywords: Crustacea, Decapoda, benthonic, taxonomy, Eocene, Ypresian, Priabonian.

\section{RESUMEN}

En este trabajo se describe un nuevo género y dos nuevas especies de cangrejos ermitaños fósiles (Anomura, Paguroidea) correspondientes a las cuencas del sur de los Pirineos en la Huesca, noreste de España. Parapetrochirus nov., con P. robustus n. gen., n. sp. como especie tipo procede del Eoceno inferior (Ypresiano) de la Formación Roda. Este fösil preserva ambos quelípedos con una notable heteroquelia, un quelipedo izquierdo más grande y una superficie cóncava sin granulaciones en las porciones superiores internas. Eocalcinus gerardbretoni $n$. sp., procede de los niveles más altos de la Formación Arguis (Priaboniano) en la localidad de Yeste. Éste se caracteriza por su forma hemisférica y un margen inferior sinuoso de la quela, lo cual difiere de la especie tipo del género. La morfología del quelípedo de estas especies permite su inclusión en las familias Diogenidae y Calcinidae, respectivamente. Los paguroideos fósiles son relativamente raros en el Eoceno de España, por tanto, la descripción de estos dos nuevos taxones fósiles incrementa la diversidad conocida del grupo. Parapetrochirus robustus $n$. gen., $n$. sp. habitaba en los sustratos siliciclásticos de ambiente prodelta y $\underline{E}$. gerardbretoni $n$. sp. fue recolectado en los últimos niveles de los rudstones coralinos, justo debajo de la influencia continental de la Formación Yeste-Arrés.

Palabras clave: Crustacea, Decapoda, bentónicos, taxonomía, Eoceno, Ypresiano, Priaboniano. 


\section{Introduction}

Hermit crabs are an interesting group of decapod crustaceans with a scattered and fragmentary fossil record (i.e., Via, 1959; Beschin et al., 2002, 2005, 2010, 2012; De Angeli et al., 2009; Garassino et al. 2009a, 2009b; Pasini and Garassino, 2010a, 2010b; Pasini and Garassino, 2011; Fraaije et al., 2011, 2015, 2020; Garassino et al., 2014; Schweigert et al., 2013; Fraaije, 2014; Hyžný et al., 2016; De Angeli and Caporiondo, 2017; Ossó, 2020; Pasini et al., 2020). The vast majority of this group has a very specialized morphology bearing a poorly mineralized and asymmetric abdomen, as a result of a life confined to empty molluscs (e.g., Walker, 1992), or in other cavities like sponges, corals or plant remains (e.g., de Forges et al., 2001; Lemaitre, 1989, 1990). This peculiar morphology favours rapid disarticulation and most fossil remains correspond to isolated propodi (see Klompmaker et al., 2017).

Here we describe two new taxa of paguroids from the Eocene of the south-central Pyrenees Basins (Spain). Previous records of decapod crustaceans from this area are relatively common (i.e., Via, 1969, 1973; Fraaye, 1995; Fraaije and Pennings, 2006; Artal and Castillo, 2005; Van Bakel et al., 2012; Artal et al., 2013a, 2013b; Ossó et al., 2014; Dominguez and Ossó, 2016; López-Horgue and Bodego, 2017; Artal and Van Bakel, 2018a, 2018b, 2020; Ferratges et al., 2019, 2020a, 2020b; Artal and Van Bakel, 2020); but paguroids are rare and fragmentary (e.g. Via, 1959, 1969; Solé and Via, 1989; Ferratges et al., 2020a), with the exception of the semi-articulated specimen described by Ferratges et al. (2020b).

\section{Geological setting}

The southern Pyrenean basins record one of the most complete Eocene marine sedimentary successions in Europe, with decapod crustaceans previously described from several outcrops (see above). These basins were located in the south-central
Pyrenean zone (Figure 1), and paleogeographically, were located in tropical latitudes during the Paleocene-Eocene (e.g., Hay et al. 1999; Silva-Casal et al. 2017). This area corresponded to an elongated gulf connected to the west by the Bay of Biscay, on the southern limit of the axial zone of the Pyrenees (Hay et al., 1999).

The material described herein comes from two outcrops (Figure 1A); one corresponding to lower Eocene (middle Ypresian) sandstones and marly beds, in the lower part of the Roda Formation (Cuevas-Gozalo et al., 1985) (Figure 1B); and the other one corresponding to upper Eocene (Priabonian) sandstones and marly beds, in the upper part of the Arguis Formation (Millán et al. 1994; Silva-Casal et al., 2017) (Figure 1C).

The lower Eocene material was collected from the "Barranco de Bacamorta" in the neighbourhood of the village of Bacamorta, in northeaster Huesca province, Aragón, Spain (co-ordinates $\left.42^{\circ} 21^{\prime} 48^{\prime} \mathrm{N}, 0^{\circ} 24^{\prime} 56^{\prime \prime} \mathrm{E}\right)$. The Roda Formation includes highly fossiliferous intervals, which have provided an important assemblage of decapods; Zanthopsis dufuorii $(\mathrm{H}$. Milne Edwards in d'Archiac, 1850), Periacanthus ramosus Artal and Castillo, 2005, Eosymethis aragonensis Van Bakel, Guinot, Artal, Fraaije and Jagt, 2012, Collinscarcinus obliquesulcatus Artal and Van Bakel, 2020, Archaeoportunus isabenensis Artal, Ossó and Domínguez, 2013, Gaudipluma bacamortensis Artal, Van Bakel, Fraaije and Jagt, 2013, have been previously documented. The material was collected from the upper portion of the beds bearing Gaudipluma bacamortensis in limestones of the Roda Formation, near to Bacamorta.

The upper Eocene material comes from Yeste, a small village in north Huesca province, Aragón, Spain (co-ordinates 42 $23^{\prime} 09^{\prime \prime} \mathrm{N}, 0^{\circ} 40^{\prime} 42^{\prime \prime} \mathrm{W}$ ). The Arguis Formation includes highly fossiliferous intervals, which have provided an important assemblage of decapods (see Ferratges et al., 2020a). The material was collected from the last carbonatic levels of sequence IV in the rail cut of the train going from Huesca to Canfranc. This corresponds approximately with the last levels of coral rudstones just below the Yeste-Arrés Formation, represented in section 11 of Morsilli et al. (2012). 

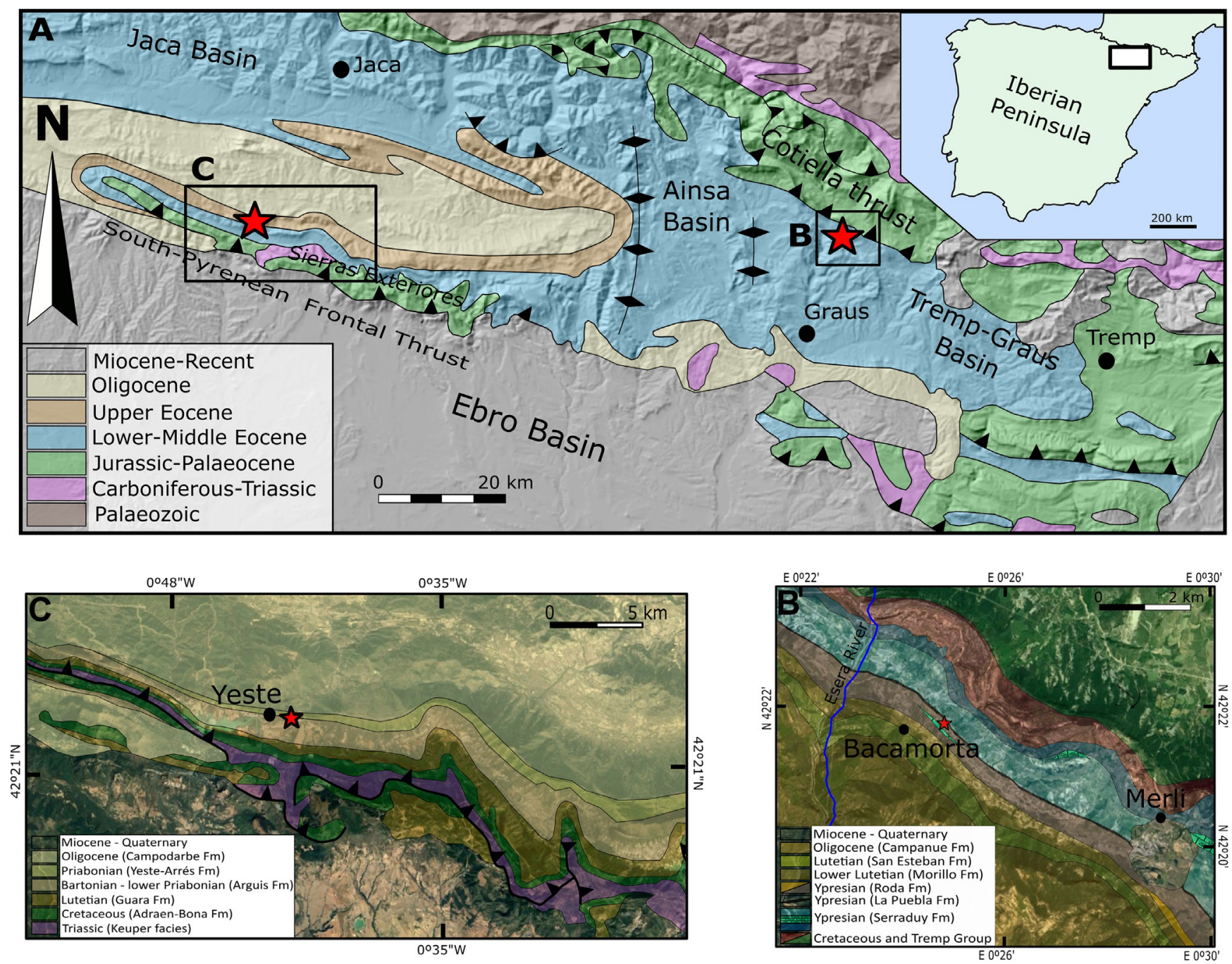

Figure 1 Geological and stratigraphic setting of the studied material. A: Location of the Tremp-Graus and Jaca-Pamplona Basins in the South-Central Pyrenean zone (modified from Dreyer et al., 1999). The red stars show the location of the studied outcrops (B, C).

From an environmental point of view, the Roda Formation represents a prodelta environment and the last intervals of the Arguis Formation are the last episodes of reef influence within the mesophotic ecological zone.

\section{Material and methodology}

Parapetrochirus robustus n. gen., n. sp. was collected from a single block of limestone that after preparation contained two chelipeds which that probably correspond to the same individual. Evidence supporting that both chelipeds correspond to the same individual include 1) close proximity of both chelipeds within the same rock and 2) morphological features of both chelipeds including a concavity without ornamentation in the upper inner portions and similar granulation pattern 3) there are a left and right cheliped, its sizes fit one specimen. E. gerardbretoni n. sp. was instead recovered from a carbonate block, with no other remains of crustaceans.

The specimens were prepared using a Micro Jack 2 air scribe (Paleotools) and binocular magnifying, and later photographed dry and coated with 
ammonium chloride sublimate. Detailed photography of the cheliped surfaces was made using a Nikon d7 100 camera (Nikon, Tokyo, Japan) with a macro 60-mm-lens.

The specimens are deposited in the Museo Geológico del Seminario de Barcelona (MGSB) and the Museo de Ciencias Naturales de la Universidad de Zaragoza (Spain) (MPZ). Eocalcinus gerardbretoni $\mathrm{n}$. sp. was collected under permit EXP: 032/2018 from the Servicio de Prevención, Protección e Investigación del Patrimonio Cultural (Gobierno de Aragón). Parapetrochirus robustus n. gen., n. sp. was collected in the early 80 s and is housed within the historic collection of the Seminario de Barcelona.

\section{Systematic Paleontology}

Order Decapoda Latreille, 1802

Infraorder Anomura MacLeay, 1838

Superfamily Paguroidea Latreille, 1802

Family Diogenidae Ortmann, 1892

Genus Parapetrochirus n. gen.

Zoobank ID code: urn:lsid:zoobank.org:pub:92FD0E58-ED01-438B-8417-85F13C7819B6

Figures 2 and 3

Type species: Parapetrochirus robustus n. gen., n. sp., by monotypy.

Diagnosis: Heterochelid chelipeds strongly robust, left largest. Left propodus large, palm subtrapezoidal, margins inclined; fixed finger notably large, fairly strong; dorsolateral surface of propodus covered with scale-shaped tubercles; lower margin laterally compressed, keel-shaped. Right palm subrectangular, triangular in cross-section; carpus subtriangular; axis of carpal-propodal articulation oblique in relation to sagittal plane. Except for the upper mesial portions, all segments are densely covered with a characteristic squamose ornamentation.

Etymology: The name refers to the similarity of the new genus to Petrochirus Stimpson, 1858 due to its characteristic squamose ornamentation on the outer surface of the palms and dactylus.
Material: Two chelipeds of large size, with four articulated segments, merus, carpus, propodus (propodus comprises palm plus fixed finger) and dactylus. The number of the only specimen known and holotype is MSGB68569. Measurements: left propodus length: $51.93 \mathrm{~mm}$; left manus length: $28.75 \mathrm{~mm}$; left manus height: $26.58 \mathrm{~mm}$; right manus length: $29.84 \mathrm{~mm}$; right manus height: $20.04 \mathrm{~mm}$.

Type locality: Bacamorta, Huesca Province, Spain.

Type horizon: Roda Formation, lower Eocene (middle Ypresian).

$$
\begin{gathered}
\text { Parapetrochirus robustus n. sp. } \\
\text { Zoobank ID code: urn:lsid:zoobank. } \\
\text { org:act:EB43F1F0-76DD-4B9F-AB0D- } \\
\text { 7837682A5462 }
\end{gathered}
$$

Diagnosis: As for the genus, by monotypy.

Etymology: From the Latin word "robustus", meaning robust.

Description: Paguroid of large size with markedly heterochely. Left propodus largest and conspicuously robust, palm subtrapezoidal, with oblique margins, converging towards the carpus; palm longer than high, higher distally, at the movable finger junction. Upper margin straight, fairly inclined, lower margin straight, also inclined. Both margins with dentiform tubercles. Inner and outer surface of palm densely tuberculated, covered with closely spaced squamose granules. Fixed finger extremely robust, distal tip of finger directed upwards; lower margin arched in the first portion; extremely keeled in the distal portion; occlusal edge bearing some few large denticles. Dactylus unknown.

Right cheliped large. Palm subrectangular, fairly longer than high, with the upper and lower margins straight, parallel, bearing small denticles. Carpo-propodial articulation sinuous. The ornamentation of the inner and outer surfaces consists of squamose closely spaced tubercles. Fixed finger long, straight, incomplete; the occlusal edge bearing some few strong teeth. Dactylus long, with semi-circular section, distal tip of finger curved, 


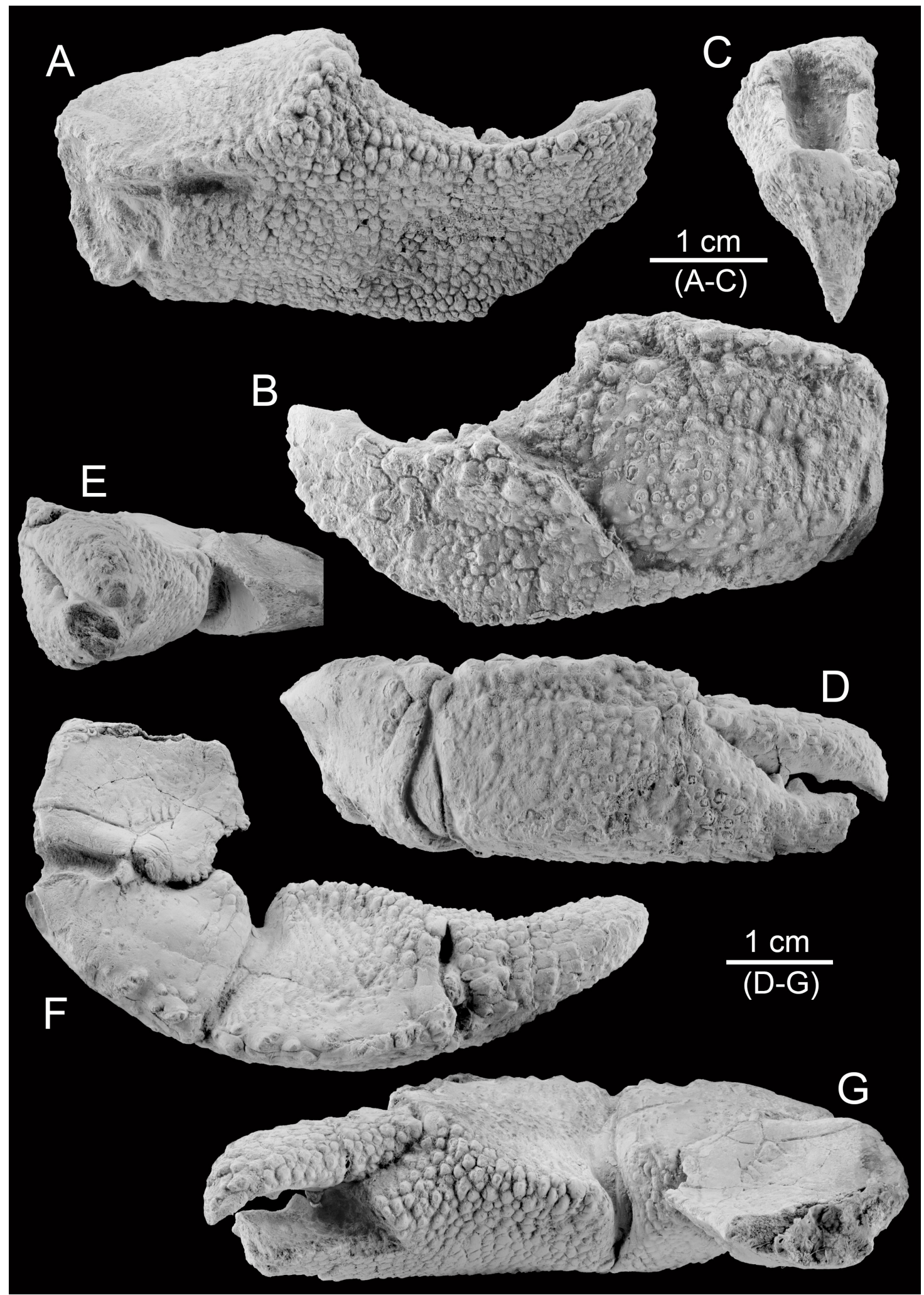

Figure 2 Parapetrochirus robustus n. gen., n. sp. (MGSB68569) from the Ypresian Roda Formation (Bacamorta, Huesca, Spain). A: lateral view of inner side of left chela; B: lateral view of outer side of left chela; C: frontal view of left chela; D: lateral view of outer side of right chela; E: frontal view of right cheliped; F: upper view of right cheliped; G: lateral view of inner side of right cheliped. Specimen whitened with ammonium chloride sublimated. 
directed downwards; occlusal edge bearing few teeth. Both fingers covered with dense squamose granules. Inner and outer surfaces bearing scarce, small, setal pits. Carpus stout, subtriangular, with a strong extension for the articulation with the merus; mesial portion without ornamentation; upper margin with denticles; outer surface densely granulated. Merus subtrapezoidal, stout, with a large rounded extension and a notable concavity for the articulation with the carpus. Mesial portion nearly flat, somewhat concave, without ornamen- tation, lower margin strongly ridged. All segments in both chelipeds exhibit a notable concavity, without ornamentation, and a strong ridge, in the upper portion of the mesial view.

Remarks: The main characters of the new taxon fit the general diagnosis of the extant and extinct Diogenidae (McLaughlin, 2003; McLaughlin et al., 2007; De Angeli and Caporiondo, 2017). The general morphology of chelipeds, like shape and size of the propodus, the ornamentation, and the notable heterochely confirms affinities with 
different genera within the family. Thus, we can assign with confidence Parapetrochirus n. gen. to Diogenidae (see also McLaughlin et al., 2010).

Nevertheless, diagnostic characters of the studied specimen justify the description of a new genus. The combination of a robust subtrapezoidal palm, the extraordinarily large size and stout aspect of the fixed finger in the left propodus; with appreciable concavities in the upper mesial portions of the left and right chelipeds constitute an important difference with all other extinct and extant genera assigned to the Paguroidea (McLaughlin et al., 2010; De Angeli and Caporiondo, 2017; Schweitzer and Feldmann, 2001).

Diogenes Dana, 1851, seems a close genus to Parapetrochirus $\mathrm{n}$. gen. due to the notable differences in shape and size between the two chelipeds, being the left one the larger. The right cheliped presents important similarities, such as the general shape and the dense ornamentation (McLaughlin, 2003; Ferratges et al., 2020b). However, the new taxon exhibits important differences in the left cheliped including a robust propodus, with an especially large and broad fixed finger, extremely keeled lower margin and a concave upper margin.

Some Italian fossil records appear to be superficially close to the new genus, as Calcinus agnoensis Beschin, De Angeli, Checchi and Zarantonello, 2005 or Petrochirus savii Beschin, De Angeli, Checchi and Zarantonello, 2012 (De Angeli and Caporiondo, 2017). The former exhibits a subcircular left chela, with arched margins, whereas Parapetrochirus n. gen. has a subtrapezoidal palm, with the margins inclined. The latter, is surprisingly assigned to the genus Petrochirus, indicating that has subequal chelipeds, while Petrochirus is diagnosed by having unequal chelipeds.

Other Italian representatives recovered from Eocene levels, as Pagurus valdagnensis Beschin, De Angeli, Checchi and Zarantonello, 2012 or Eocalcinus cavus Beschin, Busulini, De Angeli and Tessier, 2002 (Beschin et al., 2012). These fossils look superficially similar because of the shape of the propodus, with a robust fixed finger. Nevertheless, the large concavities in both chelipeds, and the peculiar left propodus provide important morphological differences. Petrochirus mezi Lörenthey, 1909 (Beschin et al., 2006, p. 99, fig. 9a, b) is larger and more robust than Parapetrochirus n. gen. In addition, it has a very different outline and the lower and upper margins do not have keels.

We can exclude the belonging of the new genus to Petrochirus Stimpson, 1858 having the right cheliped bigger than the left (McLaughlin, 2003). The right chela seems similar. However, the fossil species of Petrochirus need to be revised (Bermúdez et al., 2017; De Angeli and Caporiondo, 2017; Vega et al., 2008) since most of them were erected based upon very fragmentary material or just because a superficial appearance due to the dense and characteristic squamose ornamentation.

North American representatives of the superfamily, with very complete chelipeds also look superficially similar, as Paguristes hokoensis Schweitzer and Feldmann, 2001 or Pagurus malloryi Schweitzer and Feldmann, 2001. The former can be easily distinguished due to the subequal chelipeds, with thin and elongated fixed fingers; the latter exhibits a right cheliped larger than the left, as diagnostic in the genus Pagurus Fabricius, 1775.

Other families as Coenobitidae with terrestrial habitats, and peculiar left chelae or Xylopaguridae, which presents a notable asymmetry in the chelipeds and an especial habitat, are easily distinguished despite the common shared characters within the superfamily.

Family Calcinidae Fraaije, Van Bakel and Jagt, 2017

Genus Eocalcinus Via, 1959

Type species: Eocalcinus eоcenicus Via, 1959, by original designation.

Species: Eocalcinus albus Beschin, Busulini and Tessier, 2010; E. gerardbretoni n. sp. (herein); E. cavus Beschin, Busulini, De Angeli and Tessier, 2002; E. eocenicus Via, 1959.

Eocalcinus gerardbretoni $\mathrm{n}$. sp. Zoobank ID code: urn:lsid:zoobank. org:act:73E19EE8-9C1E-4C5A-809585347BA99F8F 


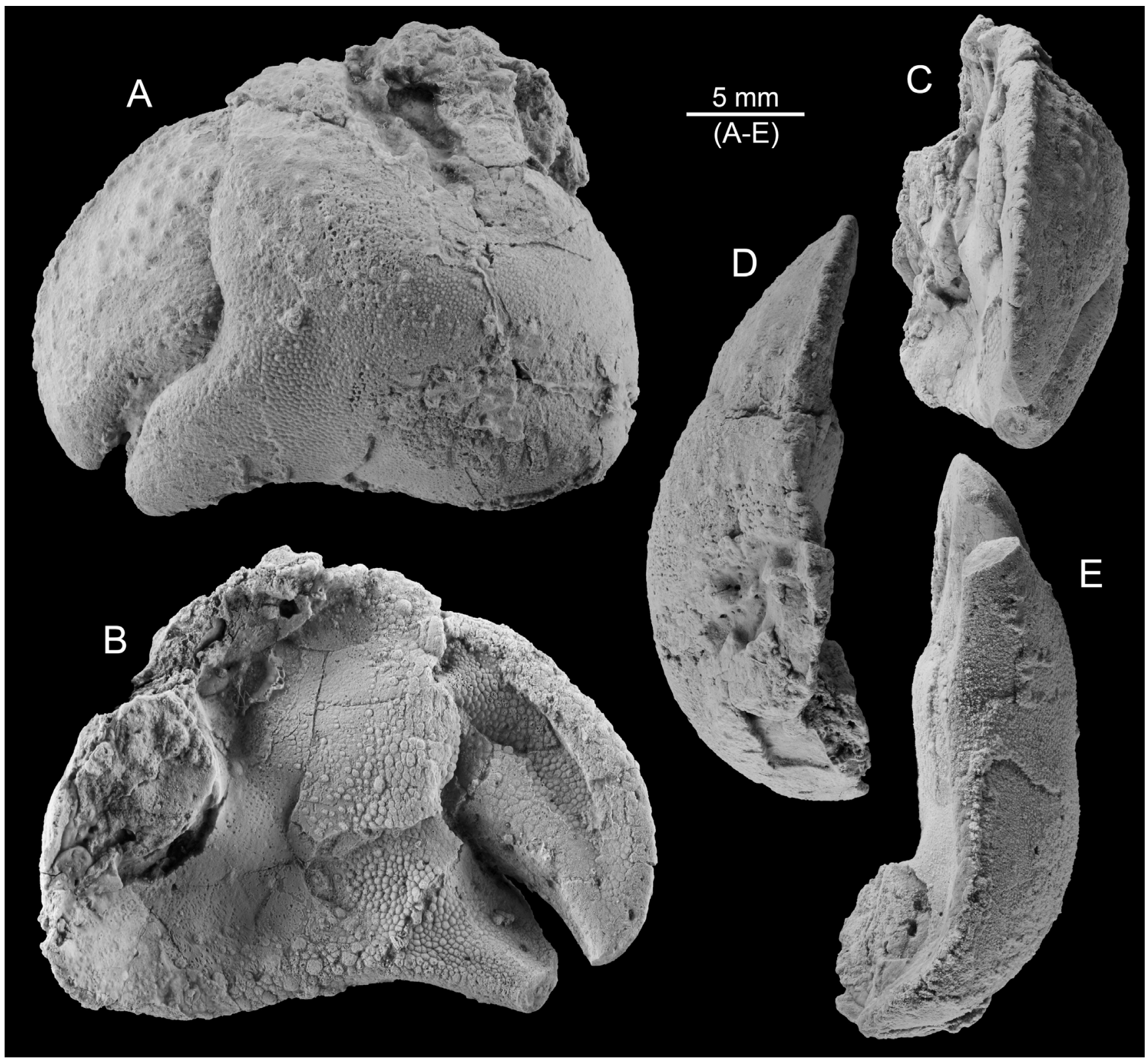

Figure 4 Eocalcinus gerardbretoni n. sp. (MPZ 2020/617) from the Priabonian levels of the Arguis Formation (Yeste, Huesca, Spain) A: lateral view of outer side of left chela; B: lateral view of inner side of left chela; C: frontal view of left chela; D: upper view of left chela; E: inferior view of left chela. Specimen whitened with ammonium chloride sublimated.

Diagnosis: Left propodus hemicircular, stout. Palm higher than long; lower margin sinuous both in lateral and lower view. Fixed finger with occlusal edge sinuous, obliquely oriented.

Etymology: The species is dedicated to the French paleocarcinologist Gérard Breton, for a lifetime dedicated to the study of geology and paleontology and special interest in decapod crustaceans.
Material: Single specimen corresponding to the left chelae. Holotype MPZ 2020/617. Propodus length $23.30 \mathrm{~mm}$; manus length: $20.76 \mathrm{~mm}$; manus height: $20.02 \mathrm{~mm}$.

Type locality: Yeste, Huesca, Spain.

Type horizon: Last carbonate level of the Arguis Formation in section 11 of Morsilli et al.,(2012).

Description: Stout left propodus planoconvex and subcircular. Lower margin sharp, strongly 

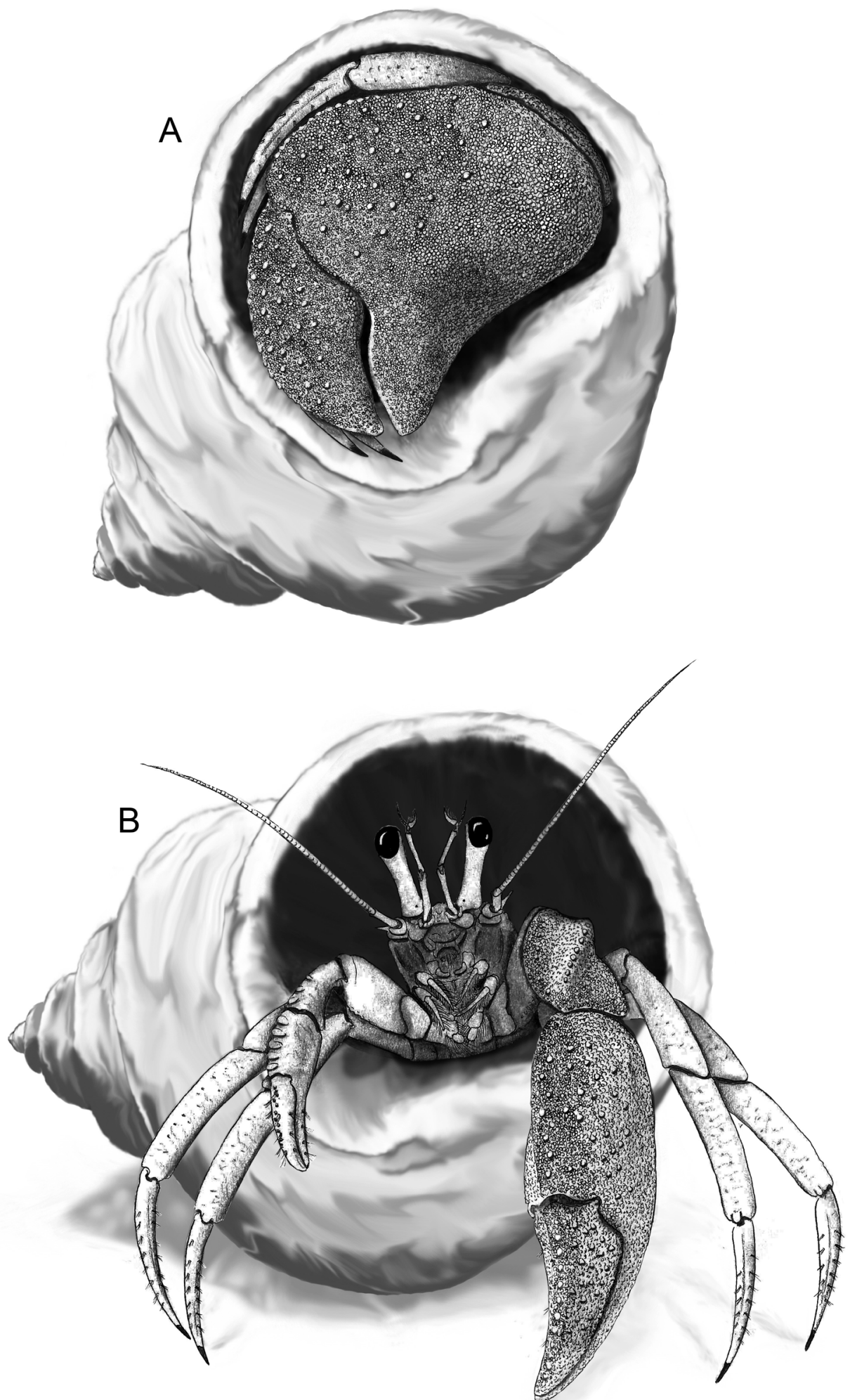

Figure 5 Idealized reconstruction of Eocalcinus gerardbretoni n. sp. A: reconstruction of the defensive position and the opercular function of the left cheliped; B: reconstruction of the walking position. The right cheliped has been based on Eocalcinus eocenicus Via, 1959, recently described by Ossó (2020). The parts not preserved in the fossil material have been tentatively inferred from closely related modern taxa. 
sinuous, in lateral and lower, inferior view; outer surface strongly convex; inner surface concave. Palm slightly higher than long, with a strong concavity at the base of the fixed finger. Fixed finger short, robust, with the first portion of the occlusal edge concave, and after strongly arched (strongly convex). Dactylus very robust, triangular in cross-section, with the occlusal edge concave, obliquely oriented, smooth. Ornamentation, on the fixed finger and lower portion of the palm, is densely covered with small granules, very close together (pavement-like) and very uniform. Upper portion of palm and dactylus is covered with circular, small granules of similar size alternated with some larger granules.

Remarks: The studied specimen can be assigned to Eocalcinus based upon the general outline of the left chela, being hemicircular in shape; the lower margin of the propodus that is concave in the middle portion; the upper margin of the palm which is broadly arched; the fixed robust finger, without teeth in the occlusal edge, joining tightly the movable finger; the dactylus, that exhibits a broadly arched upper margin; and the whole chela is densely ornamented with small granules.

We justify the description of the new species $E$. gerardbretoni based upon a more subcircular general outline; the palm is somewhat higher than long; a lower margin convex in the proximal portion and concave in the middle; an occlusal margin of the fingers sinuous; a fixed finger notably short, stout, a lower margin with a strong concavity in the first portion and a strong convexity in the median portion; and granulation in the lower portion of the palm with elongated small granules, obliquely oriented.

The type species, E. eocenicus, shows some differences with $E$. gerardbretoni n. sp. with a chela more hemielliptical in shape; propodus longer than high, the palm being elongated; the lower margin of the propodus is nearly straight, only slightly concave in the middle portion; the fixed finger has straight margins; the dactylus is nearly straight in the occlusal edge, and exhibits notable small teeth in the upper margin; the ornamentation in the lower portion of the palm consists of very small circular granules, very uniformly distributed (Via, 1959).

Eocalcinus cavus Beschin, Busulini, De Angeli and Tessier, 2002 has a more elongated chela; the palm longer than high; the lower margin of the propodus is nearly straight, only weakly concave; the fixed finger is much more elongated, and the occlusal margin is only somewhat arched; the lower portion of the palm bears larger granules (Beschin et al., 2002; De Angeli and Caporiondo, 2017). Comparison with E. albus, Beschin, Busulini and Tessier, 2010, is almost impossible because this species was described based upon only a single dactylus. However, this dactylus has a totally straight occlusal margin, and the upper margin is gently denticulated (Beschin et al., 2010).

All other species of Eocalcinus with the exception of the type species are represented by the left chelae (or a single dactylus of the left chelae in the case of E. albus). Recent finds of the right chelae of E. eocenicus allowed the assignment of this genus to the family Calcinidae (Ossó, 2020). The strong heterochely of Eocalcinus and its comparison with similar morphology in modern taxa (i.e. Coenobita), suggests the use of the left chela as an operculum that fitted tightly with the aperture of the host shell (Figure 5A).

\section{Final remarks and conclusions}

The record of Eocene paguroids in Spain is poor and often fragmentary. Via (1959) described Pagurus marceti, Pagurus marini and Eocalcinus eocenicus based on very fragmentary material. Ferratges et al. (2020b) recently described a new and very complete specimen of Diogenes augustinus comprising both chelae, locomotory legs and the cephalic shield which clearly provide important morphological information. The description of Parapetrochirus robustus n. gen., n. sp. and Eocalcinus gerardbretoni n. sp. increases our knowledge and known number of paguroids in the Spanish Eocene. The former represents an interesting find in prodelta marls of 
the Roda Formation. The latter appears in the last levels of reef influence of the Arguis Formation and increases the spatial and temporal distribution of Eocalcinus to the western Pyrenees.

\section{Acknowledgements}

This work has been supported by the projects CGL2017-85038-P subsidized by the Spanish Ministry of Science and Innovation, the European Regional Development Fund, and Project E1820R Aragosaurus: Recursos Geológicos y Paleoambientes of the government of Aragón-FEDER. The research of Fernando A. Ferratges is funded by a FPU Grant (Spanish Ministry of Science and Innovation). Isabel Pérez provided photographic assistance. The staff of the MGSB allowed the study of their historical decapod collections. We are also grateful to the reviewers Alessandro Garassino (Loma Linda University, CA - USA) and René Fraaije (Oertijdmuseum Boxtel, The Netherlands) who greatly improved the resulting manuscript.

\section{References}

Artal, P., Castillo, J., 2005, Periacanthus ramosus (Crustacea, Decapoda), nueva especie del Eoceno inferior de Huesca (Aragón, España): Batalleria, 12, 39-44.

Artal, P., Ossó, A., Domínguez, J.L., 2013a, Archaeoportunus isabenensis, a new genus and species of portunoid crab (Crustacea, Decapoda) from the lower Eocene of Huesca (Spain): Boletín de la Sociedad Geológica Mexicana, 65(2), 307-317. https://doi. org/10.18268/bsgm2013v65n2a12

Artal, P., Van Bakel, B.W.M., 2018a, Aethrids and panopeids (Crustacea, Decapoda) from the Ypresian of both slopes of the Pyrenees (France, Spain): Scripta Musei Geologici Seminarii Barcelonensis, 22, 3-19.

Artal, P., Van Bakel, B.W.M., 2018b, Carpiliids (Crustacea, Decapoda) from the Ypresian
(Eocene) of the Northeast of Spain: Scripta Musei Geologici Seminarii Barcinonensis, 22, 20-36.

Artal., P., Van Bakel, B.W.M., 2020, A new xanthid crab (Decapoda, Brachyura) from the Lower Eocene (Ypresian) of Huesca (Aragón, Spain): Neues Jahrbuch für Geologie und Paläontologie Abhandlungen, 296(1-2), 19-27. https://doi.org/10.1127/ njgpa/2020/0885

Artal, P., Van Bakel, B.W.M., Fraaije, R.H.B., Jagt, J.W.M. 2013b, New retroplumid crabs (Crustacea, Brachyura, Retroplumidae Gill, 1894) from the Eocene of Huesca (Aragon, Spain): Zootaxa, 3652, 343-352. https:// doi.org/10.11646/zootaxa.3652.3.3

Bermúdez, H.D., Vega-Sandoval, F.A., Vega, F.J., 2017, Neogene decapod crustacean from the Caribbean of Colombia: Boletín de la Sociedad Geológica Mexicana, 69(3), 655-668. https://doi.org/10.18268/ bsgm2017v69n3a8

Beschin, C., Busulini, A., De Angeli, A., Tessier, G., 2002, Aggiornamento ai crostacei di cava "Main" di Arzignano (Vicenza - Italia settentrionale) (Crustacea, Decapoda): Studi e Ricerche. Associazione Amici del Museo, Museo Civico "G. Zannato", Montecchio Maggiore (Vicenza), 7-28.

Beschin, C., Busulini, A., Tessier, G., 2010, Crostacei decapodi dell'Eocene medio (Bartoniano) di Soave (Verona - Italia nordorientale): Studi e Ricerche. Associazione Amici del MuseoMuseo Civico 'G. Zannato', Montecchio Maggiore, 17, 11-28.

Beschin, De Angeli, Checchii, A., Zarantonello, G., 2005, Crostacei eocenici di Grola presso Spagnago (Vicenza, I talia settentrionale): Studi e Ricerche. Assoziacione Amici del Museo, Museo Civico "G. Zannato" Montecchio Maggiore, 12, 5-35.

Beschin, C., De Angeli, A., Checchi, A., Mietto, P., 2006, Crostacei del Priaboniano di Priabona (Vicenza-Italia settentrionale): Lavori, Società Veneziana di Scienze Naturali, 31, 95-112.

Beschin, C., De Angeli, A., Checchi, A., 
Zarantonello, G., 2012, Crostacei del giacimento eocenico di Grola presso Spagnago di Cornedo Vicentino (Vicenza, I talia settentrionale) (Decapoda, Stomatopoda, Isopoda): Museo di Archeologia e Scienze Naturali "G. Zannato" Montecchio Maggiore, $100 \mathrm{p}$.

Cuevas-Gozalo, M., Donselaar, M.E., Nio, S.D., 1985, Eocene clastic tidal deposits in the Tremp-Graus Basin (Prov. of Lérida and Huesca), in Mila, L.D., Rosell , J.,(eds.), Excursion Guidebook, $6^{\text {th }}$ European Regional Meeting: Lérida, Spain: International Association of Sedimentologists, I.A.S., 6, 215-266.

Dana, J.D., 1851, Conspectus crustaceorum quae in orbis terrarum circumnavigatione, Carolo Wilkes e classe reipublicae foederatae duce, lexit et descripsit: Proceedings of the Academy of Natural Sciences, Philadelphia, 5, 267-272. https://doi.org/10.5962/bhl. title. 53615

De Angeli, A., Caporiondo, F., 2017, I granchi eremiti (Crustacea, Decapoda, Anomura, Paguroidea) dell'Eocene medio di cava "Main" di Arzignano (Vicenza, Italia settentrionale): Studi Trentini di Scienze Naturali, 96, 11-32.

De Angeli, A., Garassino, A., Pasini G., 2009, New reports of anomurans and brachyurans from the Cenozoic of Tuscany (Italy): Atti della Società italiana di Scienze naturali e del Museo civico di Storia naturale in Milano, 150 (2), 163-196.

de Forges, B.R., Chan, T.Y., Corbari, L., Lemaitre, R., Macpherson, E., Ahyong, S.T., Ng, P.K., 2001, The MUSORSTOM-TDSB deep-sea benthos exploration programme (1976-2012): An overview of crustacean discoveries and new perspectives on deep-sea zoology and biogeography: Tropical Deep-Sea Benthos, 185, 1-13.

Dominguez, J.L., Ossó, A., 2016, New decapod fauna at midway of the Tethys Sea and Atlantic Ocean; Central Pyrenees of Huesca (Aragon, Spain), in: $6^{\text {th }}$ Symposium on Mesozoic and Cenozoic Decapod Crustaceans, Charbonnier, S., (ed.): France, Villers-sur-Mer, Normandy, 23-24.

Dreyer, T., Corregidor, J., Arbues, P., Puigdefäbregas, G., 1999, Architecture of the tectonically influenced Sobrarbe deltaic complex in the Ainsa Basin, northern Spain: Sedimentary Geology, 127, 127-169.https:// doi.org/10.1016/s0037-0738(99)00056-1

Fabricius,J.C., 1775, Systema entomologiae, sistens insectorum classes, ordines, genera, species, adiectis, synonymis, locis, descriptionibus, observationibus: Flensburg and Leipzig, Kortii, 832 p. https://doi.org/10.5962/bhl. title.36510

Ferratges, F. A., Zamora, S., Aurell, M., 2019, A new genus and species of Parthenopidae MacLeay, 1838 (Decapoda: Brachyura) from the lower Eocene of Spain: Journal of Crustacean Biology, 39(3), 303-311. https:// doi.org/10.1093/jcbiol/ruz014

Ferratges, F.A., Zamora, S., Aurell, M., 2020a, Systematics and distribution of decapod crustaceans associated with late Eocene coral buildups from the southern Pyrenees (Spain), in Jagt,J.W.M., Fraaije,R.H.B. van Bakel, B.W.M., Donovan, S.K., Mellish, G., (eds.), A lifetime amidst fossil crustaceans: a tribute to Joseph S.H. Collins (1927-2019): Neues Jahrbuch für Geologie und Paläontologie Abhandlungen, 296, 79-100. https://doi. org/10.1127/njgpa/2020/0893

Ferratges, F.A., Zamora, S., Aurell, M., 2020b, A new hermit crab (Anomura, Paguroidea) out of its shell from the middle Eocene Arguis Formation, (Huesca, Spain): Acta Palaeontologica Polonica, 65 (4), 787-792. https://doi.org/10.4202/app.00779.2020

Fraaije, R.H.B., 2014, Diverse Late Jurassic anomuran assemblages from the Swabian $\mathrm{Alb}$ and evolutionary history of paguroids based on carapace morphology: Neues Jahrbuch für Geologie und Paläontologie Abhandlungen, 262, 247-255. https://doi. org/10.1127/0077-7749/2014/0419 
Fraaije, R.H.B., Beschin, C., Busulini, A., Tessier, G., Jagt, J.W.M., Van Bakel, B.W.M., 2020, foecalcinus, a new hermit crab genus from the Eocene of northern Italy: the second Cenozoic representative of the extant family Calcinidae (Decapoda, Anomura), in Jagt, J.W.M., Fraaije,R.H.B., Van Bakel, B.W.M., Donovan, S.K., Mellish, C.,(eds.), A lifetime amidst fossil crustaceans: a tribute to Joseph S.H. Collins (1927-2019): Neues Jahrbuch für Geologie und Paläontologie Abhandlungen, 296, 101-105. https://doi.org/10.1127/ njgpa/2020/087 1

Fraaije, R.H.B., Pennings, H.W., 2006, Crab carapaces preserved in nautiloid shells from the Upper Paleocene of Huesca: Pyrenees, Spain: Revista Mexicana de Ciencias Geológicas, 23(3), 361-363.

Fraaije, R.H.B., Van Bakel, B.W.M., Iserbyt, A., Jagt, J.W.M., 2011, New extinct Paguroidea (Crustacea, Decapoda, Anomura), with the first example of capsulated setae from the fossil record: Neues Jahrbuch für Geologie und Paläontologie Abhandlungen, 262, 247-255. https://doi. org/10.1127/0077-7749/2011/0199

Fraaije, R.H.B., Van Bakel, B.W.M., Jagt, J.W.M., 2015, A new Albian hermit crab (Anomura, Paguridae) from France - another example of capsulated setae in an extinct form: Neues Jahrbuch für Geologie und Paläontologie Abhandlungen, 273(3), 353-359. https:// doi.org/10.1127/njgpa/2015/0511

Fraaije, R.H.B., Van Bakel, B.W.M., Jagt, J.W.M., 2017, A new paguroid from the type Maastrichtian (Upper Cretaceous, the Netherlands) and erection of a new family: Bulletin de la Société Géologique de France, 187, 155-158. https://doi.org/10.1051/ bsgf/2017185

Fraaye, R.H.B., 1995, A new raninid crab, Pseudorogueus Rangiferus (Decapoda, Crustacea), from the Eocene of Spain: Estudios Geológicos, 51(1-2), 65-67. https:/ / doi.org/10.3989/egeol.95511-2284
Garassino, A., De Angeli, A., Pasini G., 2009a, A new hermit crab (Crustacea, Anomura, Paguroidea) from the Late Cretaceous (Cenomanian) of Lebanon: Atti della Società italiana di Scienze naturali e del Museo civico di Storia naturale in Milano, 150 (2), 215-228.

Garassino, A., De Angeli, A., Pasini G., 2009b, In situ hermit crab (Crustacea, Anomura, Paguroidea) from the early Eocene (Ypresian) of NE Italy: Atti della Società italiana di Scienze naturali e del Museo civico di Storia naturale in Milano, 150 (2), 229-238.

Garassino, A., De Angeli, A., Pasini, G., Hyžný, M., 2014, The decapod fauna (Axiidea, Anomura, Brachyura) from the late Pleistocene of Trumbacà, Reggio Calabria (Calabria, southern Italy): Natural History Sciences, Atti della Società italiana di Scienze naturali e del Museo civico di Storia naturale in Milano, 1 (2), 119-130. https:// doi.org/10.4081/nhs.2014.60

Hay, W.W., De Conto, R., Wold, G.N., Wilson, K.M., Voigt, S., Schulz, M., Wold-Rossby, A., Dullo, W.C., Ronov, A.B., Balukhovsky, A.N., Soeding, E., 1999, Alternative global Cretaceous paleogeography, in Barrera, E., Johnson, C. (eds.), The evolution of Cretaceous ocean-climate systems: Geological Society of America, Special Papers, 332, 1-47. https://doi: 10.1130/ 0-8137-2332-9.1

Milne-Edwards, H., 1850, Formation nummulitique de l'Espagne, in d'Archiac: Histoire des progrès de la géologie de 1.834-1859: France, Au lieu des séances de la Société 304.

Hyžný, M., Fraaije, R.H.B., Martin, J.E., Perrier, V., Sarr, R., 2016, Paracapsulapagurus poponguinensis, a new hermit crab (Decapoda, Anomura, Paguroidea) from the Maastrichtian of Senegal: Journal of Paleontology, 90, 1133-1137. https://doi. org/10.1017/jpa.2016.65 
Klompmaker, A.A., Portell, R.W., Frick, M.G., 2017, Comparative experimental taphonomy of eight marine arthropods indicates distinct differences in preservation potential: Palaeontology, 60, 773-794. https://doi. org/10.1111/pala.12314

Latreille, P.A., 1802, Histoire naturelle, générale et particulière, des Crustacés et des Insects, Familles Naturelles des Genres. F. Tome 3, Dufart, Paris, 467p. https://doi.org/10.5962/bhl. title. 15764

Lemaitre, R., 1989, Revision of the genus Parapagurus (Anomura: Paguroidea: Parapaguridae), including redescription of the western Atlantic species: Zoologische Verhandelingen, 253 (1), 1-106.

Lemaitre, R., 1990, A review of eastern Atlantic species of the family Parapaguridae (Decapoda: Anomura: Paguroidea): Journal of Natural History, 24, 219-240. https:// doi.org/10.1080/00222939000770141

López-Horgue, M.A., Bodego, A., 2017, Mesozoic and Cenozoic decapod crustaceans from the Basque-Cantabrian basin (Western Pyrenees): new occurrences and faunal turnovers in the context of basin evolution: Bulletin de la Société Géologique de France, 188(14), 1-28. https://doi.org/10.1051/ bsgf/2017180

MacLeay, W.S., 1838, On the brachyurous decapod Crustacea brought from the Cape by Dr. Smith, in Smith, A., (ed.), Illustrations of the Annulosa of South Africa; being a portion of the objects of natural history chiefl $y$ collected during an expedition into the interior of South Africa, under the direction of Dr. Andrew Smith, in the years 1834, 1835. and 1836; fitted out by "The Cape of Good Hope Association for Exploring Central Africa": London, Smith, Elder, and Co., 53-71.

McLaughlin, P.A., 2003, Illustrated keys to families and genera of the superfamily Paguroidea (Crustacea: Decapoda: Anomura), with diagnoses of genera of Paguridae: Memoirs of Museum Victoria, 60, 111-144. https:// doi.org/10.24199/j.mmv.2003.60.16

McLaughlin, P.A., Komai, T., Lemaitre, R., Rahayu, D.L., 2010, Annotated checklist of anomuran decapod crustaceans of the world (exclusive of the Kiwaoidea and families Chirostylidae and Galatheidae of the Galatheoidea) part I - Lithodoidea, Lomisoidea and Paguroidea: The Raffles Bulletin of Zoology, 23, 5-107.

McLaughlin, P.A., Lemaitre, R., Sorhannus, U., 2007, Hermit crab phylogeny: a reappraisal and its "fall-out": Journal of Crustacean Biology, 27(1), 97-115. https://doi. org/10.1651/s-2675.1

Millán, H., Aurell, M., Melendez, A., 1994, Synchronous detachment folds and coeval sedimentation in the Prepyrenean external Sierras (Spain): a case study for a tectonic origin of sequences and systems tracts: Sedimentology, 41, 1001-1024. https://doi. org/10.1111/j.1365-3091.1994.tb01437.x

Morsilli, M., Bosellini, F.R., Pomar, L., Hallock, P., Aurell, M., Papazzoni, C.A., 2012, Mesophotic coral buildups in a prodelta setting (late Eocene, southern Pyrenees, Spain): a mixed carbonate-siliciclastic system: Sedimentology, 59(3), 766-794. https://doi. org/10.1111/j.1365-3091.2011.01275.x

Ortmann, A., 1892, Die Dekapoden-Krebse des Strassburger Museums IV. Die Abtheilungen Galatheidea und Paguridea: Zoologischen Jahrbiicher, Abtheilung fiir Systematik, Geographie und Biologic der Tiere, 6, 241-326.

Ossó, A., 2020, New data on Eocalcinus eocenicus Via Boada, 1959 (Decapoda: Anomura: Calcinidae), from the Middle Eocene of Catalonia: Bulletin of Mizunami Fossil Museum, 47, 105-110.

Ossó, A., Domínguez, J.L., Artal, P., 2014, Pyreneplax basaensis new genus, new species (Decapoda, Brachyura, Vultocinidae) from the Priabonian (Late Eocene) of the Pyrenees of Huesca (Aragon, Spain), and remarks on 
the genus Lobonotus A. Milne-Edwards, 1863: Treballs del Museu de Geologia de Barcelona, 20, 33-43. https://doi.org/10.32800/ tmgb.2014.20.0033

Pasini, G., Garassino, A., 2010a, In situ hermit crabs (Crustacea, Anomura, Paguroidea) from the Pliocene of Parma and Reggio Emilia (Emilia Romagna - N Italy): Atti della Società italiana di Scienze naturali e del Museo civico di Storia naturale in Milano, 151 (1), 105-112.

Pasini, G., Garassino, A., 2010b, New report of Dardanus substriatus (A. Milne-Edwards, 1861) (Anomura, Paguroidea, Diogenidae) from the Early Pliocene of Ficulle, Terni (Umbria, Central Italy): Atti della Società italiana di Scienze naturali e del Museo civico di Storia naturale in Milano, 151 (1), 113-116.

Pasini, G., Garassino, A., 2011, Anapagurus mamertinus n. sp. (Anomura, Paguroidea, Paguridae) from the Pliocene of S. Antonio, Capo Milazzo (Sicily, S Italy): Atti della Società italiana di Scienze naturali e del Museo civico di Storia naturale in Milano, 152 (1), 57-62. https://doi.org/10.4081/ nhs. 2011.57

Pasini, G., Garassino, A., Nyborg, T., Dunbar, S.G., Fraaije, R.H.B., 2020, In situ hermit crab (Anomura, Paguroidea) from the Oligocene Pysht Formation, Washington, USA: Neues Jahrbuch für Geologie und Paläontologie, Abhandlungen, 295 (1), 17-22. https://doi. org/10.1127/njgpa/2020/0865

Schweigert, G., Fraaije, R.H.B., Havlik, P., Nützel, A., 2013, New Early Jurassic hermit crabs from Germany and France: Journal of Crustacean Biology, 33(6), 802-817.https:// doi.org/10.1163/1937240x-00002191

Schweitzer, G.E. Feldmann, R.M., 2001, New Cretaceous and Tertiary decapod crustaceans from western North America: Bulletin of Mizunami Fossil Museum, 28, 173-210

Silva-Casal, R., Payros, A., Martínez-Braceras, N., Aurell, M., 2017, The Eocene marine sedimentation in the southern Pyrenean Basin: a basin-slope-platform transect, in International Meeting of Sedimentology 2017 (33rd IAS \& 16th ASF Joint Meeting): EHU-UPV Argitalpen Zerbitzua, University of Toulouse, 56.

Solé, J., Via, L., 1989, Crustacis Decàpodes fòssils dels Països Catalans (Recopilació i actualització de dades des de 1855 a 1988: Batalleria, 2, 23-42.

Stimpson, W., 1858, Prodromus descriptionis animalium evertebratorum, quae in expeditione ad oceanum Pacifi cum septentrionalem, a Republica Federate missa, Cadwaldaro Ringgold et Johanne Rodgers ducibus, obseravit et descripsit: Proceedings of the Academy of Natural Sciencs of Philadelphia, 7, 225-252. https:// doi.org/10.5962/bhl.title.51447

Van Bakel, B.W.M., Guinot, D., Artal, P., Fraaije, R.H.B., Jagt, J.W.M., 2012, A revision of the Palaeocorystoidea and the phylogeny of raninoidian crabs (Crustacea, Decapoda, Brachyura, Podotremata): Zootaxa, 3215(1), 1-216. https://doi.org/10.11646/ zootaxa.3215.1.1

Vega, F.J., Nyborg, T., Coutiño, M.A., HernándezMonzón, O., 2008, Review and additions to the Eocene decapod crustacea from Chiapas, México: Bulletin of Mizunami Fossil Museum, 34, 51-71.

Via, L., 1959, Decápodos fósiles del Eoceno español: Boletín del Instituto Geológico y Minero de España, 70, 331-402.

Via, L., 1969, Crustáceos decápodos del Eoceno español: Pirineos, 480.

Via, L., 1973, Datos para el estudio de los crustáceos decápodos del Eoceno circumpirenaico: Pirineos, 107, 55-70.

Walker, S.E., 1992, Criteria for recognizing marine hermit crabs in the fossil record using gastropod shells: Journal of Paleontology, 66, 535-558. https://doi.org/10.1017/ s0022336000024410

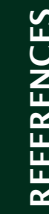

